\title{
Mycosis fungoides and variants
}

INSERM

\section{Source}

INSERM. (1999). Orphanet: an online rare disease and orphan drug data base. Mycosis fungoides and variants. ORPHA:178566

Mycosis fungoides (MF) and its variants represent the most common forms of cutaneous T-cell lymphomas. The term MF is restricted to the classical form characterized by the slow progression of patches, plaques and tumors, and to variants with a similar indolent course. 